\title{
STUDY OF EFFECT OF LATERAL LOADS ON DIFFERENT OUTRIGGER SYSTEMS WITH BELT TRUSS
}

\author{
S Sushma $^{1}$, Dhanalakshmi ${ }^{2}$ \\ ${ }^{I}$ Department of Civil Engineering, Manipal Institute of Technology, Manipal, Karnataka, India \\ sushma.shyamsundar@gmail.com \\ ${ }^{2}$ Department of Civil Engineering, Manipal Institute of Technology, Manipal, Karnataka, India \\ dhanushetty85@gmail.com
}

\begin{abstract}
Outrigger systems are one of the efficient lateral load resisting structural forms used in design of tall buildings. The better performing system among All Steel, All concrete and Mixed Steel-Concrete outrigger systems, for a given site specific lateral loading is the main interest of study. Parameters like base shear, overturning moment and top displacement are compared in the multi outrigger system, with one outrigger fixed at the top and the position of the second varied. Mixed Steel and concrete system is found to be the efficient system. Second outrigger anywhere between 0.4 to 0.6 times the total heights of the building is found to be optimum.
\end{abstract}

Keywords: Multi Outrigger System, Belt Truss, Materials, ETABS

\section{INTRODUCTION}

Tall buildings are preferred nowadays both in developed and developing countries due to the growing population demands. The expansion horizontally is constrained because of the possibility of loss of agricultural lands in the due process, the necessity to be closer to the city centre and also the increasing land values. Thus, expanding skywards is sought. Also, tall buildings become the landmarks of the city they are located it.

A building is considered tall, when, it is governed by the lateral forces acting on it. Thus, there exists a need for a structural form which also acts as a lateral load resisting system. One such system is an Outrigger System. A basic outrigger system consists of core, outrigger arms and mega columns. In order to enhance the performance of the system, belt truss running around the periphery are used. This entire system can be made up of either steel or concrete completely, or can be mixed steel and concrete in nature where the core is of concrete and the outrigger arms are of steel.

B. S. Taranath [1] gave a theoretical approach to understanding the concept of outrigger systems by a simple core-outrigger-mega column model. The effect of different types of loadings, like, uniformly distributed, uniformly varying loads on the behaviour of the system were studied with the help of numerical equations.

B. S. Smith [2] helped understand the effects of core to outrigger $(\alpha)$ and outrigger to mega column $(\beta)$ relative rigidities on the performance of outrigger systems. The ratio of $\alpha$ to $\beta$ was represented by $\omega$, which was used in the performance studies.

F. Nouri [3] investigated the behaviour of 2D steel outrigger systems with different bracing configurations adopted for the core. The investigation was carried out by linking the OpenSees software to MatLab. X bracing was found to be the better performing configuration.

K.Kamath et al [4] investigated the behaviour of an all concrete multi outrigger system by varying the locations of the two outriggers and also the value of $\beta$ in order to find the optimum locations of the two outriggers for better performance in terms of overturning moment, base shear and top displacements.

In our previous work [5], the behaviour of 3D all steel multi outrigger systems subjected to lateral loads with different bracing configurations was studied. The configurations studied were single diagonal, X, K and Knee bracings. Also, the optimum location of the outriggers was also found.

The response to loadings of different materials is different. Hence, the behaviour of a steel structure is different from that of a concrete structure for the same loads considered. In continuation to the previous work, this study investigates the better performing outrigger system based on the material it is made up of for a given site specific lateral loads. 


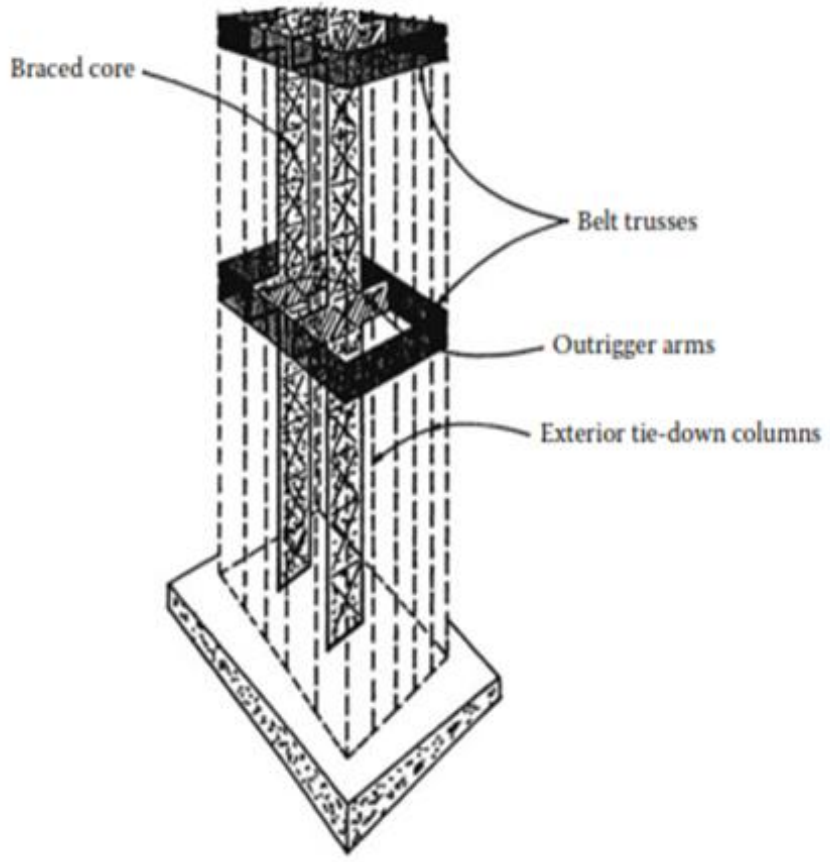

Figure 1: Structural schematic of an outrigger system

\section{METHODOLOGY}

Since the of effect of materials used on the behaviour of the structure is to be studied, the outriggers are modelled broadly in three categories- All Steel, All Concrete and Mixed Steel and Concrete- representing the materials used for the core and outrigger arms respectively. In addition, a multi outrigger system is considered, with one outrigger fixed at the top and the location of the second outrigger is varied from 0.25 to 0.75 times the total height of the building. This is done in order to find the optimum location of the second outrigger with the first being fixed at the top.

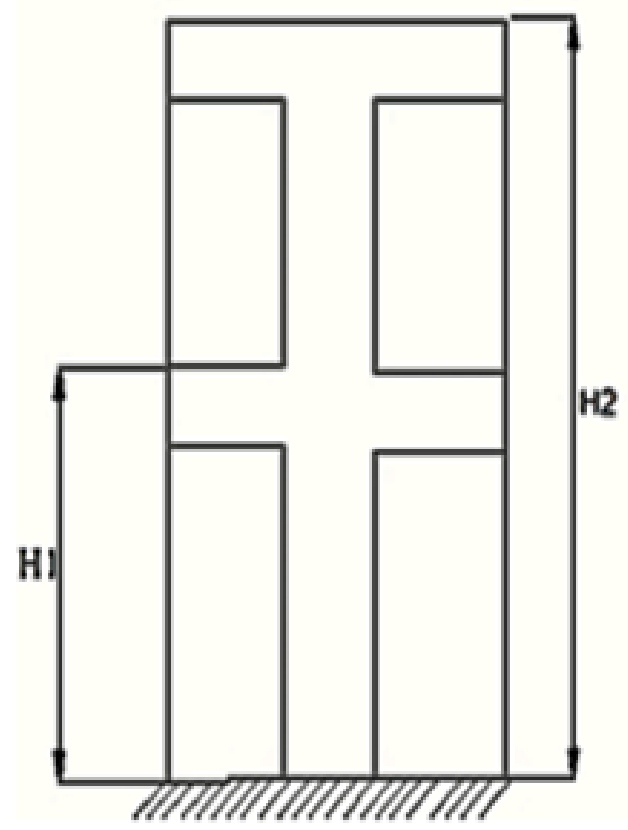

(a)

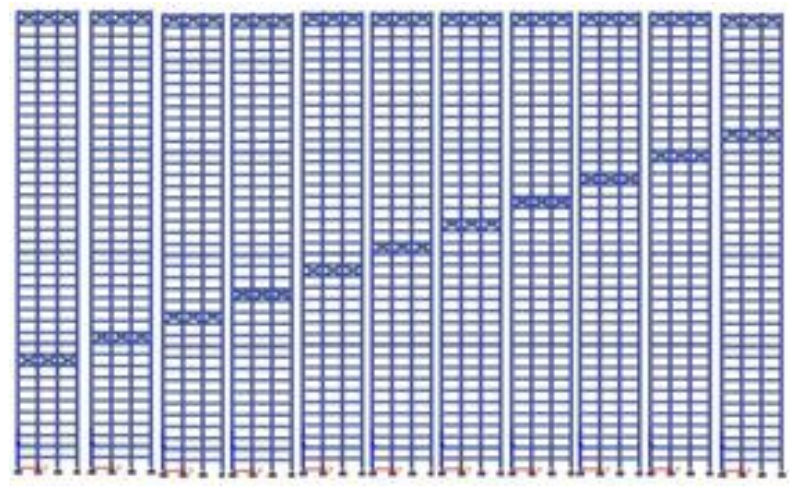

(b)

Figure 2: (a) Relative height of outriggers with first outrigger fixed at the top $(\mathrm{H} 2)$ and the varying location heights of the second outrigger (H1); (a) schematic representation; (b) locations of outriggers in the study models considered

The effect of belt truss on an outrigger system is studied by modelling it into the three different outrigger systems considered and the optimum position of the second outrigger is determined in the same manner as above.

\section{MODEL DESCRIPTION}

\section{A. Model Properties}

The plan of the model used in the study consists of a 40 storey 3 bay, 4 framed 3D structure, and storey height being $3.5 \mathrm{~m}$ [4]. Two outrigger levels are considered, one fixed at the top and the other with variable location along the height. The outriggers are one storey deep. A belt truss, made up of $\mathrm{X}$ bracing runs on the periphery of the outrigger floors in the models with belt truss.

The steel outriggers are made up of $\mathrm{X}$ bracing, the beams are ISWB 500, columns are designer sections and bracings are circular tubes of $600 \mathrm{~mm}$ diameter having a thickness of $60 \mathrm{~mm}$.

The concrete outrigger walls are $500 \mathrm{~mm}$ thick, core wall $300 \mathrm{~mm}$ thick and columns $750 \mathrm{X} 750 \mathrm{~mm}$ in cross section.

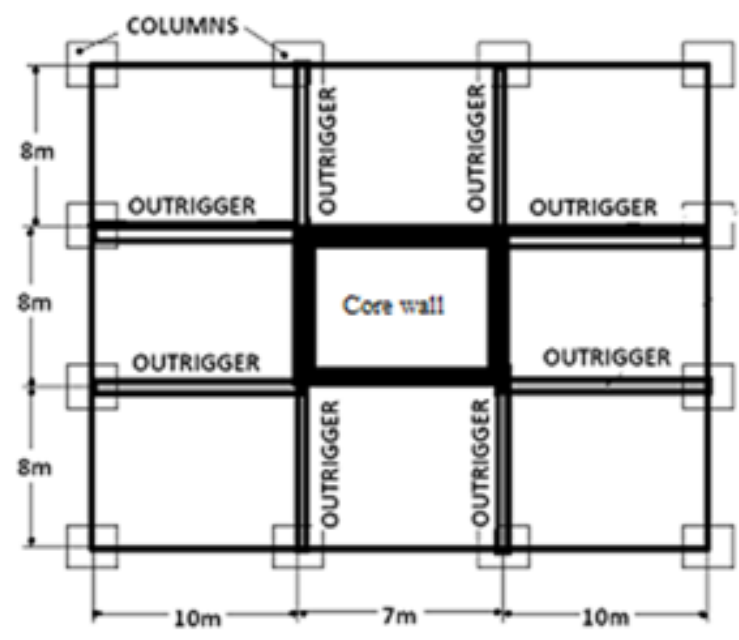

(a) 

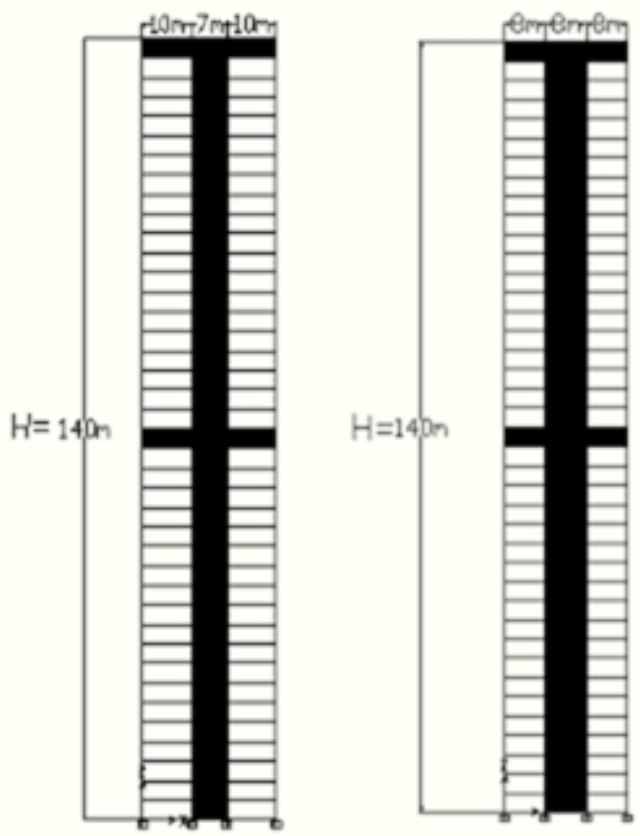

(b)

Figure 3: (a) Plan; (b) Elevation

\section{B. Loads considered}

The loads applied on the structure are self-weight of the elements and lateral loads- wind and seismic. The structure is considered to be located in Bangalore. The wind load is defined as per IS 875 (Part 3) [6] and the seismic definition as per IS 1893 (Part 1) [7]. A response reduction factor of 3 and an importance factor of 1.5 has been considered.

Table 1: Location of Second Outrigger Relative To Top Outrigger

\begin{tabular}{|c|c|}
\hline $\mathbf{H}_{\mathbf{1}} / \mathbf{H}_{\mathbf{2}}$ & LOCATION OF OUTRIGGER \\
\hline 0.25 & Storey 10 \\
\hline 0.30 & Storey 12 \\
\hline 0.35 & Storey 14 \\
\hline 0.40 & Storey 16 \\
\hline 0.45 & Storey 18 \\
\hline 0.50 & Storey 20 \\
\hline 0.55 & Storey 22 \\
\hline 0.60 & Storey 24 \\
\hline 0.65 & Storey 26 \\
\hline 0.70 & Storey 28 \\
\hline 0.75 & Storey 30 \\
\hline
\end{tabular}

Equation (1) is used to calculate the fundamental time period of the structure which is input in the seismic load definition in the software.

$\mathrm{T}_{0}=0.075 \mathrm{~h}^{0.75}$
Table 2: Load Combinations Considered

\begin{tabular}{|c|c|}
\hline Wind & Seismic \\
\hline $1.5(\mathrm{DL} \pm \mathrm{WLx})$ & $1.5(\mathrm{DL} \pm \mathrm{EQx})$ \\
\hline $1.5(\mathrm{DL} \pm \mathrm{WLy})$ & $1.5(\mathrm{DL} \pm \mathrm{EQy})$ \\
\hline $0.9 \mathrm{DL} \pm 1.5 \mathrm{WLx}$ & $0.9 \mathrm{DL} \pm 1.5 \mathrm{EQx}$ \\
\hline $0.9 \mathrm{DL} \pm 1.5 \mathrm{WLy}$ & $0.9 \mathrm{DL} \pm 1.5 \mathrm{EQy}$ \\
\hline
\end{tabular}

In the above table, DL represents the self-weight of the structural members, $\mathrm{EQ}_{\mathrm{x}}$ and $\mathrm{EQ}_{\mathrm{y}}$ are the seismic load definitions and $\mathrm{WL}_{\mathrm{x}}$ and $\mathrm{WL}_{\mathrm{y}}$ are the wind load definitions in the two mutually perpendicular horizontal directions.

\section{RESULTS}

\section{A. Top Displacement}

The variation of top displacements of the all concrete, all steel and mixed steel and concrete with and without belt truss for the different locations of outriggers along the height of the structure is as shown in the figures 4 to 7 .

It can be seen that the addition of belt truss to an outrigger system has an effect on the top displacement criteria. The all concrete system performs better for the seismic loading with belt truss while the all steel system gives the least top displacement for the other criteria.

The reduction in the top displacement due to the addition of belt truss in case of seismic loading is $6 \%$ and that for wind loading is $10 \%$ on an average.

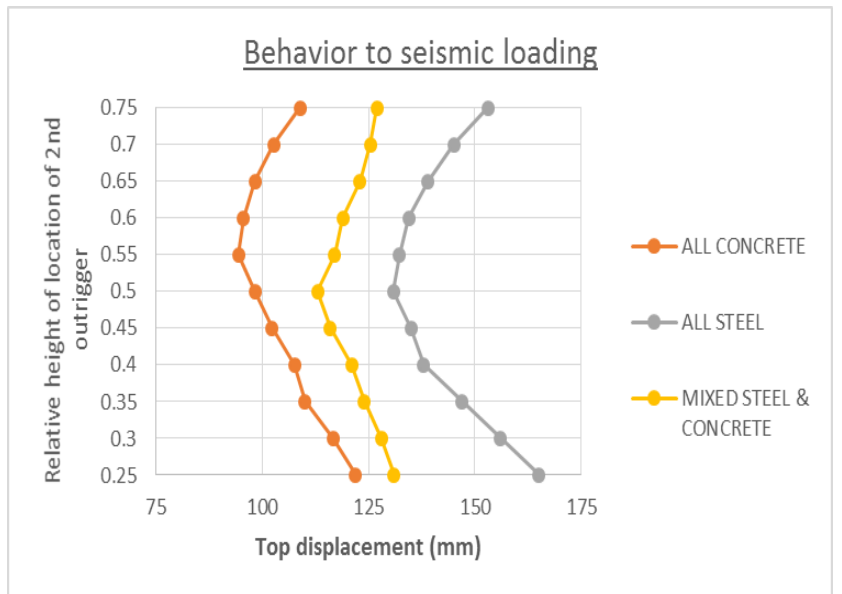

Figure 1. Variation of top displacement due to seismic loading for different outrigger systems without belt truss with variable location of the 2 nd outrigger.

The load combinations [7] considered are as in the Table 2. 


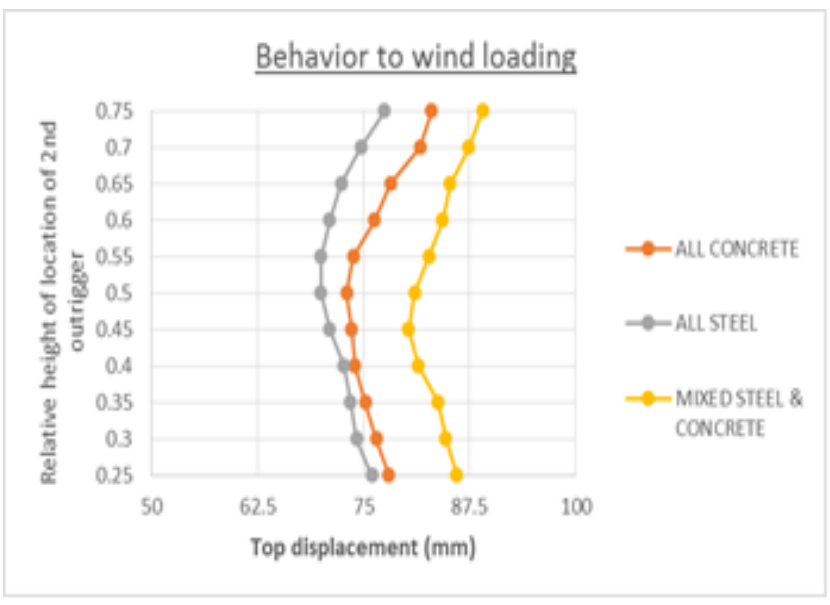

Figure 2. Variation of top displacement due to wind loading for different outrigger systems without belt truss with variable location of the 2 nd outrigger.

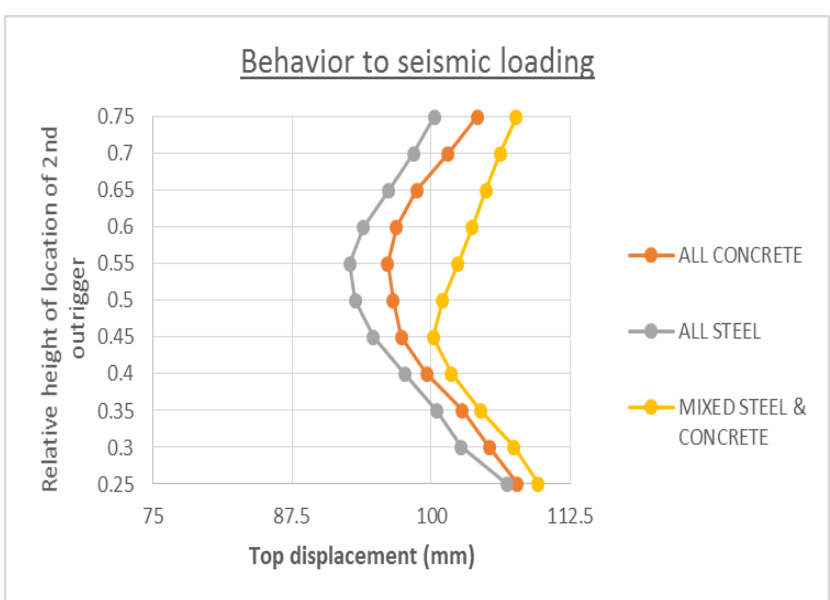

Figure 3. Variation of top displacement due to seismic loading for different outrigger systems with belt truss with variable location of the 2 nd outrigger.

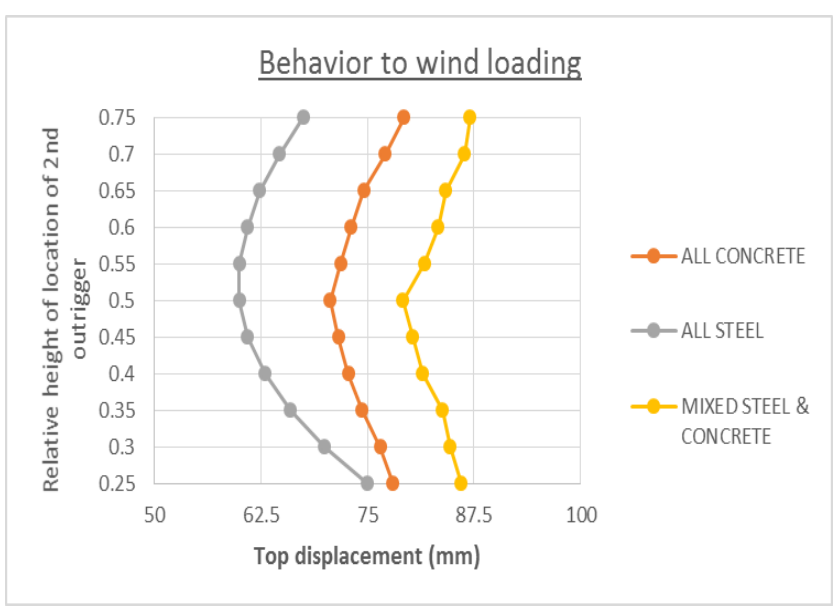

Figure 5. (a) Variation of top displacement due to wind loading for different outrigger systems with belt truss with variable location of the 2 nd outrigger.

\section{B. Base Shear}

Tables 3 and 4 show the variation of base shear for the outrigger systems with and without belt truss. The base shear is found to be unaffected by varying the location of second outrigger.

Mixed Steel and Concrete outrigger system is found to be system experiencing the least base shear out of the three systems considered.

The difference in base shears in the outrigger systems with and without outrigger systems is found to be within $5 \%$.

Table 3. Base Shear Of Outrigger System Without Belt Truss Subjected To Seismic And Wind Loading

\begin{tabular}{|c|c|c|}
\hline \multirow{2}{*}{$\begin{array}{c}\text { Outrigger System } \\
\text { without Belt Truss }\end{array}$} & \multicolumn{2}{|c|}{ Base Shear } \\
\cline { 2 - 3 } & $\begin{array}{c}\text { Seismic } \\
\text { loading }\end{array}$ & $\begin{array}{c}\text { Wind } \\
\text { loading }\end{array}$ \\
\hline All Concrete & 1886 & 1508 \\
\hline All Steel & 5347 & 4277 \\
\hline Mixed Steel \& Concrete & 1797 & 1437 \\
\hline
\end{tabular}

Table 4. Base Shear of Outrigger System With Belt Truss Subjected To Seismic And Wind Loading

\begin{tabular}{|c|c|c|}
\hline \multirow{2}{*}{$\begin{array}{c}\text { Outrigger System with } \\
\text { Belt Truss }\end{array}$} & \multicolumn{2}{|c|}{ Kase Shear } \\
\cline { 2 - 3 } & $\begin{array}{c}\text { Seismic } \\
\text { loading }\end{array}$ & $\begin{array}{c}\text { Wind } \\
\text { loading }\end{array}$ \\
\hline All Concrete & 1961 & 1569 \\
\hline All Steel & 5421 & 4337 \\
\hline Mixed Steel \& Concrete & 1873 & 1499 \\
\hline
\end{tabular}

\section{Overturning Moment}

The variation of the overturning moment at the base is found to be less than $1 \%$ when the location of the outrigger is varied. This small difference is thus considered negligible.

Tables 5 and 6 show the maximum overturning moment of the three types of outriggers systems considered. The effects of wind and seismic loadings on overturning moments can be seen.

Table 5. Overturning Moment of Outrigger System Without Belt Truss Subjected To Seismic And Wind Loading

\begin{tabular}{|c|c|c|}
\hline \multirow{2}{*}{$\begin{array}{c}\text { Outrigger System } \\
\text { without Belt Truss }\end{array}$} & \multicolumn{2}{|c|}{$\begin{array}{c}\text { Overturning moment } \\
\text { MNm }\end{array}$} \\
\cline { 2 - 3 } & $\begin{array}{c}\text { Seismic } \\
\text { loading }\end{array}$ & $\begin{array}{c}\text { Wind } \\
\text { loading }\end{array}$ \\
\hline All Concrete & 1963 & 1760 \\
\hline All Steel & 5507 & 4394 \\
\hline Mixed Steel \& Concrete & 1872 & 1682 \\
\hline
\end{tabular}


Table 6. Overturning Moment Of Outrigger System With Belt Truss Subjected To Seismic And Wind Loading

\begin{tabular}{|c|c|c|}
\hline \multirow{2}{*}{$\begin{array}{c}\text { Outrigger System with } \\
\text { Belt Truss }\end{array}$} & \multicolumn{2}{|c|}{$\begin{array}{c}\text { Overturning Moment } \\
\text { MNm }\end{array}$} \\
\cline { 2 - 3 } & $\begin{array}{c}\text { Seismic } \\
\text { loading }\end{array}$ & $\begin{array}{c}\text { Wind } \\
\text { loading }\end{array}$ \\
\hline All Concrete & 2043 & 1830 \\
\hline All Steel & 5587 & 4456 \\
\hline Mixed Steel \& Concrete & 1953 & 1752 \\
\hline
\end{tabular}

\section{CONCLUSIONS}

For a given location, if a tall building is to be constructed, the effects of wind along with the seismic effects should be considered. In such a case, the materials used for the construction of the building plays an important role as much as the structural system used in its behavior to the lateral loads. Thus, outrigger systems, when are decided to be incorporated in a tall building, an all concrete system behaves better for wind, while a mixed steel and concrete system performs better for seismic loads.

The contribution of belt truss to the reduction of overturning moment, base shear or the top displacement is found to be very less. Its addition to the stiffness also doesn't make much of a difference to the performance of the system. But, in comparison to the outrigger system without belt truss, the systems with belt truss performs better.

The mixed steel and concrete outrigger system tends to perform better in comparison with the other two in terms of considerable reduction in base shear and overturning moments. When the top displacement is the criteria, all steel system is a better performer.

The optimum location of the second outrigger remains between 0.4 to 0.6 times the total height of the building even in case when different materials are used in the system. Thus, the optimum location of the outrigger is not governed by material used.

\section{ACKNOWLEDGMENTS}

The authors would like to express their sincere thanks to the H.O.D, Department of Civil Engineering, Manipal Institute of Technology, Manipal and gratitude towards Civil-Aid Technoclinic Pvt. Ltd., Bangalore for their enormous help and support for carrying out the present study.

\section{REFERENCES}

[1] B. Taranath, Reinforced concrete design of tall buildings. Boca Raton: CRC Press, 2010.

[2] B. Stafford Smith and A. Coull, Tall building structures. New York: Wiley, 1991.

[3] F. Nouri and P. Ashtari, "Investigating Structural Behavior of Outrigger-braced Tall Structures", The 2013 World Congress on Advances in Structural
Engineering and Mechanics (ASEM-13), Jeju, Korea, September 8-12, 2013

[4] K. Kamath, "A Study on Static and Dynamic Behavior of Outrigger Structural System for Tall Buildings", BIJIEMS, vol. 2, no. 4, pp. 15-20, 2012.

[5] S. Sushma and Dhanalakshmi, "Investigating the Structural Behavior of Braced Steel Outrigger System to Lateral Loads", International Conference on Advances in Civil Engineering and Sustainable Construction at ACESC16 held at SRM University, March 30, 31 and April 1, 2016, Unpublished.

[6] Code Of Practice for Design Loads (Other Than Earthquake) for Buildings And Structures - Wind Loads, IS 875 (Part 3) : 1987.

[7] Criteria for Earthquake Resistant Design of Structures, Part 1: General Provisions and Buildings, IS 1893 (Part 1) : 2002 . 